\title{
National Conference: Answering the Nigerian National Question
}

\author{
Lawan Cheri, \\ Department of General Studies, Federal Polytechnic Damaturu, Nigeria.
}

\begin{abstract}
Nigeria is a country with a myriad opportunities and problems. It is the world's major producer of cassava and importer of starch, one of the largest producers of crude oil that cannot refine its oil and imports PMS, a country that produces tomatoes above national demand but also imports tomato paste. Worst still, the few infant industries are collapsing by the day due to unfavorable economic conditions leading to unemployment, crime and terrorism. On the political aspects, Nigeria tries almost all types of government will innumerable failures at all times. The parliamentary system of the first republic, the presidential system of second and fourth republics, the civilian-military diarchy of the IBB era, unitary structure under Ironsi and various military administrations have all led to wanton systemic failure. Since 1946 Nigeria is struggling to design a fiscal federal structure acceptable to its people but succeeded in creating dissatisfaction and apathy. This economic and political failure necessitates an analysis to know why things are happening the way they do and offer solutions to the problems facing the Nigerian state. Since no one can do that for Nigerians better than themselves, the call for a National Conference to discuss these issues becomes imperative. This paper uses documentary analysis to assess the views of people on the convocation of sovereign national conference, identify the challenges and hurdles that must be crossed and recommend solutions to the problems.
\end{abstract}

\section{Background to the Call for a National Conference in Nigeria}

Nigeria is a country with deep rooted ethnic, religious, regional and cultural diversities. Borrowing from the words of Huntington, Nigeria is divided along a fault line where two distinct and debatably reconcilable civilizations clash - the northern part is predominantly Muslim with Islamic orientation and culture while the southern part is predominantly Christian inclined to the Western culture. Hundreds of different nationalities that were hitherto independent of one another were rounded up by the British and divided into only two protectorates of Southern and Northern Nigeria which they later joined together in 1914 to create the present Nigeria. This British sponsored marriage of inconvenience led to the convocation of the London National Conference of 1958 where under colonial tutorship, 107 Nigerians were selected and engaged to take part in discussing issues of national significance that resulted in the Independence Constitution of 1960 which was subsequently replaced with the Republican Constitution of 1963 (Codewit, Oct. 2013).

However, the events that followed point to the failure of such conference and the constitution drafted therefrom. The Census Crises that torn the NPC/NCNC coalition apart, the Western regional crises of 1964, the first military coup and counter coup of January and July 1966, the subsequent civil war of 1967-1970 and the prolonged period of military rule that ensued thereafter points to the troubles facing the Nigerian polity.

The military government of General Murtala Muhammad realized the need to call various peoples of Nigeria to a round table in 1977 to discuss how they wanted to be government in the name of a Constitutional Assembly bordering mostly on the newly drafted constitution that was due to take effect in 1979.However, after the Constitutional Assembly submitted the draft documents, much to the dismay of Nigerians, instead of seeking the consent of the people through referendum as obtainable in other countries, the Obasanjo led Junta enacted the constitution into force through a Decree. (Daily Independent, 2013)The discussions were implemented and the constitution took effect on $1^{\text {st }}$ October 1979 only for it to be untimely truncated in 1983 owing much to the incompetence demonstrated by the civilian administration and partly to the Military's unending quest for power. In 1989, another Constitutional Assembly was convened by the then Military dictator, General Ibrahim Babangida which ushered in the 1993 constitution leading to the election and inauguration of the National Assembly and the various state governors but retained the Military headship of Babangida in what can be rightly termed the first and hopefully the last experience of civilian/military diarchy in Nigeria. Both the Assembly and the constitution they produced withered away as their initiator stepped aside (Wikipedia, 2013).

After the June 12 misadventure that resulted in the formation Shonekan led Interim National Government (ING) and subsequent power-snatch by Abacha, the country was thrown into another round of confusion with Abiola still claiming the presidency, while Abiola's associates including Ambassador Babagana Kingibe who contested alongside Abiola as Vice President accepted a ministerial slot under Abacha. With the National Democratic Coalition (NADECO) promising fire and brimstone if power is not returned to Abiola and Abacha insisting on Messianic child of necessity, the country seemed ripe for a serious skirmish. Thus in their 
usual power covetousness, the military called for National Constitutional Conference to discuss the future of the country consisting of both elected and nominated representatives which brought mixed outcome for Nigerians. It resulted in the creation of the six geopolitical zones and 13 percent derivation for oil producing states but at the same time extended Abacha's handing over date to an unspecified date. This is believed to be politically calculated by the Abacha henchmen to perpetuate their influence and camouflage their intention with seemingly legitimating endeavor of a national Conference hiding behind legitimate demands of the people such as the derivation formulae and the creation of zones to cater for minority interest.

Copying from the Abacha style, while pursuing his unconstitutional Third Term Agenda, Chief Olushegun Obasanjo convened what he termed the National Political Reform Conference (NPRC) manifestly to discuss pressing national issues but latently aimed at ensuring constitutional amendment that will guaranteeand constitutionalize his tenure elongation drive. That's why when the third term agenda crashed at the floor of the national assembly; all the recommendations of the conference suffered similar fate and died therewith.

With the present call for a National Conference, by President Goodluck Jonathan and some elites, Nigerians are divided over its viability. On one hand some Nigerians are skeptical about the motive behind the idea especially because of the previous experiences and the fact that those who were against it in the past are now tilted towards it while many others who worked persistentlyto ensure its success are now having a changed mind against it. Some writers interpret it as a pointer to pursuance of hidden personal motives instead of national objectives. "Suspicion arose partly as a result of the fact that some of those now clamoring for it are the same people who worked assiduously to frustrate its success in the immediate past when all the likelihood of its success was present. What have they seen now that was not evident in the past that has converted them like the biblical Paul on his sinister trip to Damascus?" (Daily Independent, Sept. 29, 2013). On the other side, other Nigerians feel the call is both timely and needful. Adibe, J. (Feb., 2013) asserted "the issues that the SNC seeks to resolve are crucial and vital - and must be confronted honestly and decisively if we genuinely hope to fashion out a nation out of the mosaic of nationalities that make up the Nigerian state. What is however unclear is whether the SNC is the best vehicle for resolving those vital issues"

This kind of questions and many of its likes, call for assessing the challenges facing such kind of great National Initiative and examine the prospects that the nation stand to benefit.

\section{Condition Necessitating a National Conference}

Nigeria is a federal state with prolonged history of military rule which turned it to a unitary-like structure. Over the years, the centralized command structure of the military have been deeply embedded into the system owing much to the Head of State's power to appoint and fire state governors and determine their composition, finance, functions and structure without consulting the people (Wikipedia, 2013). This also affects the principles of fairness, human rights, creation of local governments, regional autonomy and a host of other issues that need to be addressed by the people which include the following inter alia:

Resource Control: This is a longstanding, frequently debated dilemma that defies acceptable solution. Nigerians of all regions always complain of political and economic marginalization of one sort or the other. The people of the South South are known for their persistent call for realignment of resource distribution to increase the percentage of the national cake allocated base on derivation while other non-oil producing states of the other zones are in love with keeping the status quo because increasing the amount to be allocated base on derivation means reducing what goes to the other states from the distributable pool. In a meeting of the southern Nigerian Governors Forum on March 27, 2001, they resolved to support the call for fiscal federalism base on the principles of national interest, need and derivation where they defined resource control as "the practice of true federalism and natural law in which the federating units express their rights to primarily control the natural resources within their borders and make agreed contribution towards the maintenance of common services of the government at the center" (Dafinone, 2001). This sharply contrast the views in other parts of the country including many non-oil producing communities of the south that all revenues on all resources found within Nigeria belong to all people of Nigeria. In an attempt to balance the equation, the constitution maintains the latter view point with a consolatory clause to cater for the former. Section 162(1) states that "the Federation shall maintain a special account to be called "the Federation Account" into which shall be paid all revenues collected by the Government of the Federation, except the proceeds from the personal income tax of the personnel of the armed forces of the Federation, the Nigeria Police Force, the Ministry or department of government charged with responsibility for Foreign Affairs and the residents of the Federal Capital Territory, Abuja." While section 162(2) identifies the process of redistributing the national cake to include the $13 \%$ based on the principles of derivation. Other areas of consideration being "population, equality of States, internal revenue generation, land mass, terrain as well as population density; Provided that the principle of derivation shall be constantly reflected in any approved formula as being not less than thirteen percent of the revenue accruing to the Federation Account directly from any naturalresource." This legal provision however, fails to 
assuage aggrieved feelings because the call for National conference to discuss Nigeria's fiscal imbalance remain a top priority of some communities. In 1987, the Political Bureau Report discerned "none of the formula evolved at various times by a commission or by decree under different regimes since 1964 has gained general acceptability among the component units of the country" (Dafinone, 2001). This point to the level of contention the issue of resource control has reached in a country that almost entirely depends on one source of income.

Ethno-religious Crises: Another issue that advocates are insisting that the conference needs to tackle is that of the persisting, ever volatile, resource sapping ethnic and religious crises that explore the fault lines of religion, region and tribe to foment discord and aggravate hostility and mistrust among Nigerian communities. Nigeria being a plethora of ethnic groups and religious affiliations presents a difficult to manage scenario resulting in the polarization of the country along regional and religious lines.The recent Boko Haram crisis in the northeastern part of the country, the recurring farmers-herdsmen conflict in almost all the northern states, ethnic skirmishes in Plateau, Benue and the South South; and the ever resurfacing religious intolerance that is rocking the country need to be discussed and put to a halt.Most of the skirmishes borders on one or a combination of indigene/settler misunderstanding, battle over economic resources at ethnic borderlines, or crises ignited by politicians to achieve selfish political goals. Intergovernmental Relations:

Power Sharing: Due to the heterogeneous nature of the Nigerian state, there are many disgruntled voices that persistently call for devising a power sharing formula that can be acceptable to all. Such clamors are hinging on historical events that were outcomes of regional power tussles like the first and second military coups of 1966, Gideon Okar attempted coup, June 12 crises and the political imbroglio that followed the ill-health of President Umaru Musa Ya'adua. It is not disputable that all sections of a federation must be given a sense of belonging not only by having a constitutionally backed, unlimited access to the most exalted position in the federation but ensuring that such provision becomes practicable in the country.

The unfortunate days of military rule that spanned a period of 28 years resulted in the total domination of political power by the military elites of northern extraction which ignited feelings of political marginalization in the minds of the southern compatriots. This was aggravated by the annulment of the June 12 by a northern president (Ibrahim Badamasi Babangida) election which was widely believed to have been won by a southerner (Mashood Kashimawo Olawale Abiola). The political and economic crises that followed the annulment led many Nigerians to call for a national conference to address the issue of rotational presidency. Late Ken Saro Wiwa opined that Nigerians had a national question:

The issues that made up the Nigerian National question are the political structure of the country, the relationship between the different ethnic groups, the political system to be adopted in taxation, revenue generation, the relationship and responsibilities between different levels of government, fundamental human rights, social justice, prevention of the environment and the defense of the nation (Ojimba, 2012).

Though Saro Wiwa became a victim of persistent call for redesigning Nigeria, but the necessity of answering the national question is becoming glaring by the day.

Niger Delta: Although all sections of the Nigerian society have one scar or the other to claim being marginalized, the people of Niger Delta region consider themselves the "neglected bread winners" of the Nigerian family. As a result of oil exploration, extraction and production, the land is continuously becoming inhabitable, oil spillage renders their farms infertile, creates new and avoidable diseases and yet, they enjoy very little or nothing of the oil money compared to their expectations. This resulted in kidnapping oil tycoons and their workers (both foreign and domestic and the demand) and the demand of ransom by Niger Delta youth. Subsequently it gave rise to the creation of organized criminal gangs and terrorist organisations like Movement for Emancipation of the Niger Delta (MEND) that masterminded that October bombings in Abuja and many other terrorist activities in the area.

\section{Challenges Facing the Convocation of National Conference}

Suspicion and Mistrust: More than ever before, there is growing mutual distrust and skepticism and one another among Nigerians. Very few believe in others having genuine national interest and almost all delegates go to the conference as a game player trying to win it all and if possible denying others the chance of winning. The conference is generally not considered as an avenue for give and take exercise but a place for outsmarting others. This preconceived cynicism is a threat to the success of any negotiation.

Ethnic and regional bigotry: Unfortunately for Nigeria, in the $21^{\text {st }}$ century there are still "statesmen" who continue to judge issues base on parochial vested interests. The so called elders who sound regional and tribal voices and refuse to give room for youth to unite for the progress of Nigeria, serve as threat not only to the success of the conference but threaten the very existence of the country as one indivisible nation. Tribal and 
regional warlords such as the Arewa Consultative Forum, the Ohaneze Ndigbo and Afenifere are unconstitutional but powerful elite organizations that sail the Nigerian ship towards divisions and disintegration. Lack of Political will: Considering the records of national conferences in the country, most Nigerians believe that government is having ulterior motives for convening the conference. In the midst of rampant allegation of corruption against government officials, crisis of legality facing the tenure elongation of the president and the utter failure of government to contain insurgency engulfing the country, it is not misplaced opinion to describe the conference as a diversionary tactic to wade-off criticism.

It is just another ploy to keep the people busy in the face of the unworkability of the governing system, a diversionary tool from the reality of a failing social order, all with the hope that by the time the people get over the talks and debates, they would have recovered from the current mess that they have found themselves... they have used this ploy in the past to get past thorny political tickets thus earning themselves temporary reprieve only to go back to their evil ways that have contributed to put the nation under considerable stress with the result that all diagnoses now point to an imminent failure of the state called Nigeria (Daily Independent, Sept. 29, 2013).

\section{Conclusion}

Base on the foregoing discussions, the convocation of a national conference to discuss the future of Nigeria, to answer the unanswered national questions, sieve out better ways of handling national challenges and redesigning the political, economic and social structures of the country is long overdue. However, the conference must be handled with the decorum it deserves to avoid fates the visited previous conferences. Nigeria being a federal state with linguistic, cultural, religious and civilizational diversities is a confluence of strange bed fellows that must learn how to live together.

\section{Recommendations}

1. The discussions and debates must be guided by the spirit of national oneness and the indivisibility of the country as enshrined in Nigerian constitution. Issues that are capable of overheating the polity should be avoided.

2. The recommendations of the conference should be subjected to a national referendum to gauge its acceptability across the country. This is because an issue may be decided by the delegates and a wider opinion poll may consider it lopsided and unacceptable.

3. Government must show strong political and administrative will to support the conference and refuse to meddle or steer its affairs. Government must be seen as an impartial arbiter to convince people that it has hidden motives.

4. There are issues that Nigeria is already settled about such as the democracy and federalism that shouldn't be altered. However, problems bedeviling their proper operation in the Nigerian state can be debated.

5. Nigerians should be enlightened about the motives behind the conference. People shouldn't see it as theatre of ethnic and regional skirmishes where every community cheers their representative no matter how misrepresented. Nigerians must be reoriented to consider the conference as an opportunity to discuss and mend fences.

6. With the national assembly saying it is the only body of representatives duly elected by Nigerians to carry out such functions of discussing issues, the legality of the conference must be ensured and judicial interpretation must be arrived at to convince Nigerians that it is not an exercise in futility.

[1]. Daily Independent (Sept. 29, 2013) Fundamentals of a Sovereign National Conference. http://www.dailyindependent.com/category/politics Accessed: 26/01/2014.

[2]. Codewit, (Oct. 2, 2013) Nigeria: How effective will this National Conference be? http://www.codewit.com/nigerianews Accessed: 26/01/2014.

[3]. Adibe, J. (Feb., 22, 2013) Beyond a Sovereign National Conference. http://www.hollerafrica.com Accessed: 27/01/2014

[4]. Dafinone, D., (2001) Resource control, the economic and political dimension. Publication of Urhobo Historical Society. http://www.waado.org

[5]. Iyobhebhe, J. (u.d) the resource control movement in Nigeria. http://www.gamji.com

[6]. Ojimba, C. (2012) A case for and against the convocation of a sovereign national conference in Nigeria. Multidisciplinary Journal of Research Development Volume 18 No. 1, April, 2012. 